\title{
RS3PE syndrome presenting as vascular endothelial growth factor associated disorder
}

\author{
K Arima, T Origuchi, M Tamai, N Iwanaga, Y Izumi, M Huang, F Tanaka, M Kamachi, K Aratake, \\ H Nakamura, H Ida, M Uetani, A Kawakami, K Eguchi
}

Ann Rheum Dis 2005;64:1653-1655. doi: 10.1136/ard.2004.032995

\begin{abstract}
Objectives: To characterise serum concentrations of various cytokines and detection by magnetic resonance imaging (MRI) of synovial hypervascularity in patients with remitting seronegative symmetrical synovitis with pitting oedema (RS3PE) syndrome before and after corticosteroid treatment. Methods: Vascular endothelial growth factor $165\left(V E_{165}\right)$, tumour necrosis factor $\alpha$ (TNF $\alpha$ ), and interleukin $1 \beta$ (IL1 $\beta$ ) were measured by enzyme linked immunosorbent assay (ELISA) in serum samples from three patients with RS3PE syndrome. As controls, serum samples from 26 healthy volunteers, 12 patients with rheumatoid arthritis, 10 patients with systemic lupus erythematosus, 13 patients with polymyositis/dermatomyositis, 13 patients with vasculitis syndrome, and 6 patients with mixed connective tissue disease were also analysed. Synovial hypervascularity of patients with RS3PE syndrome was estimated by rate of enhancement (E-rate) in a dynamic MRI study.

Results: Serum concentrations of $\mathrm{VEGF}_{165}$ (mean (SD) 2223.3 (156.3) pg/ml) were significantly higher in patients with active RS3PE syndrome than in controls before corticosteroid treatment. TNF $\alpha$ and IL1 $\beta$ levels were similar in patients and controls. Synovial hypervascularity in affected joints and subcutaneous oedema decreased during corticosteroid treatment, in parallel with the fall in serum VEGF ${ }_{165}$. Conclusions: VEGF promotes synovial inflammation and vascular permeability in patients with RS3PE syndrome, suggesting that RS3PE can be classified as a VEGF associated disorder.
\end{abstract}

$\mathrm{R}$ emitting seronegative symmetrical synovitis with pitting oedema (RS3PE) syndrome is a rare inflammatory arthritis, first described by McCarty and colleagues in 1985, ${ }^{1}$ and is characterised by abrupt onset of marked dorsal swelling of both hands with pitting oedema. Because RS3PE syndrome is sometimes complicated by neoplastic conditions such as non-Hodgkin's lymphoma and solid tumours, ${ }^{23}$ it is speculated that some humoral factors facilitate the clinical manifestations in patients with RS3PE syndrome; however, the precise mechanisms remain to be elucidated. ${ }^{4} 5$

Vascular endothelial growth factor (VEGF) enhances angiogenesis as well as vascular permeability, and is a candidate humoral factor responsible for tumour angiogenesis. ${ }^{6}$ We studied three patients with RS3PE syndrome, who showed markedly high serum concentrations of VEGF than patients with other connective tissue diseases, and studied whether VEGF contributes to synovitis and subcutaneous oedema in patients with RS3PE syndrome.

\section{PATIENTS AND METHODS \\ Patients}

Serum samples were obtained from three patients with typical manifestations of RS3PE syndrome. As controls, serum samples from 26 healthy volunteers, 12 patients with rheumatoid arthritis, 10 patients with systemic lupus erythematosus, 13 patients with polymyositis/dermatomyositis, 13 patients with vasculitis syndrome, and 6 patients with mixed connective tissue disease were analysed. Informed consent was obtained from each patient, and the study was approved by the Institutional Review Board of Nagasaki University.

\section{Enzyme linked immunosorbent assay}

Serum concentrations of $\mathrm{VEGF}_{165}$ (major isoform of VEGF) as well as those of tumour necrosis factor- $\alpha$ (TNF $\alpha)$ and interleukin $1 \beta(\operatorname{ILl} \beta)$ in the above subjects were analysed by enzyme linked immunosorbent assay (ELISA; VEGF 165 , R\&D Systems, Inc, Minneapolis, MN, USA; TNF $\alpha$, BioSource Europe SA, Nivelles Belgium; IL1 $\beta$, Amersham Biosciences, Buckinghamshire, UK).

\section{Dynamic magnetic resonance imaging (MRI)}

MRI of both wrists and finger joints was carried out simultaneously using a $1.5 \mathrm{~T}$ system (Sigma, GE Medical Systems, Milwaukee, WI, USA) with the use of an extremity coil. Coronal $\mathrm{T}_{1}$ weighted spin echo (repetition time (TR) 450, echo delay time (TE) 13) and short time inversion recovery (STIR) (TR 3000, TE 12, $\mathrm{T}_{1}$ 160) images were acquired. Dynamic study data were obtained at 4 second intervals for 150 seconds with fast spoiled gradient echo recalled (SPGR) sequences after intravenous injection of $0.1 \mathrm{mmol} / \mathrm{kg}$ of gadolinium-diethylenetriamine (Magnevist, Schering, Germany). Post-contrast, fat suppressed $T_{1}$ weighted images (TR 600, TE 13) were acquired in axial and coronal planes after completion of the dynamic study.

Images were evaluated for the presence or absence of synovitis in 15 joints in each wrist and finger joint-that is, distal radioulnar joint, radiocarpal joint, mid-carpal joint, lst carpometacarpal joint, 2nd-5th carpometacarpal joints (together), 1st-5th metacarpophalangeal joints separately, and 1st-5th proximal interphalangeal joints separately. A dynamic curve was obtained by plotting signal intensity against time in a round region measuring approximately 2$3 \mathrm{~mm}$ placed on the site of maximum enhancement in the aforementioned 15 joints. The rate of enhancement (E-rate) was defined as the rate of increase in signal intensity over the

\footnotetext{
Abbreviations: E-rate, rate of enhancement; IL1 $\beta$, interleukin 1 $\beta$; MRI, magnetic resonance imaging; RS3PE syndrome, remitting seronegative symmetrical synovitis with pitting oedema syndrome; STIR, short time inversion recovery; TE, echo delay time; TNF $\alpha$, tumour necrosis factor $\alpha$; $T R$, repetition time; VEGF, vascular endothelial growth factor
} 
Table 1 Serum concentrations of VEGF-A, TNF $\alpha$, and IL $\beta$ in various connective tissue diseases

\begin{tabular}{lcll}
\hline Connective tissue disease & $\begin{array}{l}\text { VEGF-A } \\
(\mathbf{p g} / \mathbf{m l})\end{array}$ & $\begin{array}{l}\text { TNF } \alpha \\
(\mathbf{p g} / \mathbf{m l})\end{array}$ & $\begin{array}{l}\text { IL1 } \beta \\
(\mathbf{p g} / \mathbf{m l})\end{array}$ \\
\hline RS3PE syndrome $(\mathrm{n}=3)$ & $2223.3(156.3)^{*}$ & $26.3(20.8)$ & $0.67(0.81)$ \\
RA $(\mathrm{n}=12)$ & $711.0(401.7)$ & $19.9(13.7)$ & $0.61(0.39)$ \\
SLE $(\mathrm{n}=10)$ & $309.9(140.6)$ & $34.2(19.4)$ & $0.32(0.16)$ \\
MCTD $(\mathrm{n}=6)$ & $682.3(575.0)$ & $51.8(27.7)$ & $0.48(0.39)$ \\
PM/DM $(n=13)$ & $324.2(188.9)$ & $22.6(10.9)$ & $0.32(0.24)$ \\
Vasculitis syndrome $(\mathrm{n}=13)$ & $736.1(475.5)$ & $27.3(14.2)$ & $0.90(1.38)$ \\
\hline
\end{tabular}

RS3PE syndrome, remitting seronegative symmetrical synovitis with pitting oedema syndrome; RA, rheumatoid arthritis; SLE, systemic lupus erythematosus; MCTD, mixed connective tissue disease; PM/DM, polymyositis/ dermatomyositis.

Data are mean (SD) of the indicated number of patients.

* $p<0.0001 v$ other connective tissue diseases by Student's $t$ test.

Table 2 Serum concentrations of VEGF 165 and E-rate of dynamic MRI during corticosteroid treatment

\begin{tabular}{|c|c|c|c|c|c|c|}
\hline \multirow[b]{2}{*}{$\begin{array}{l}\text { Patient } \\
\text { No }\end{array}$} & \multicolumn{3}{|c|}{ VEGF $_{165}(\mathrm{pg} / \mathrm{ml})$} & \multicolumn{3}{|l|}{ E-rate } \\
\hline & $\begin{array}{l}\text { Before } \\
\text { treatment }\end{array}$ & $\begin{array}{l}\text { After } \\
\text { treatment }\end{array}$ & $\begin{array}{l}\text { Mean (SD) } \\
\text { inhibition (\%) }\end{array}$ & $\begin{array}{l}\text { Before } \\
\text { treatment }\end{array}$ & $\begin{array}{l}\text { After } \\
\text { treatment }\end{array}$ & $\begin{array}{l}\text { Mean (SD) } \\
\text { inhibition (\%) }\end{array}$ \\
\hline 1 & 2341 & 393 & & 19.6 & 10.9 & \\
\hline 2 & 2283 & 605 & $60.9 *(30.6)$ & 15.4 & 10.7 & $31.5+(12.4)$ \\
\hline 3 & 2046 & 1516 & & 9.7 & 7.8 & \\
\hline
\end{tabular}

steep linear region of the curve and was used as a measure of hypervascularity of the tissue.

\section{Statistical analysis}

Data were expressed as mean (SD). Statistical analysis was performed using Student's $t$ test. Values of $\mathrm{p}<0.05$ were considered significant.

\section{RESULTS}

\section{Serum concentrations of cytokines}

Table 1 summarises the serum concentrations of the cytokines. As shown in table 1, no significant differences in TNF $\alpha$ and ILl $\beta$ serum concentrations were noted between RS3PE syndrome and other connective tissue diseases; however, markedly high serum VEGF $_{165}$ levels were found in patients with RS3PE syndrome. Because VEGF $_{165}$ serum concentrations in other connective tissue diseases were comparable with those found in previous reports, ${ }^{78}$ the high serum $V_{E G F} F_{165}$ was considered to be specific for RS3PE syndrome. TNF $\alpha$ and IL1 $\beta$ were not detected in serum samples from healthy volunteers (data not shown), and serum concentrations of $\mathrm{VEGF}_{165}$ in these subjects were also low (data not shown).

\section{MRI in patients with RS3PE syndrome}

Table 2 shows the mean E-rate of 30 joints (both wrists and finger joints) in three patients with RS3PE syndrome before and after 1 month of corticosteroid treatment. Synovial hypervascularity determined by the E-rate was reduced by corticosteroid treatment in all the three patients in parallel with the fall of serum VEGF (table 1). Subcutaneous oedema shown by a STIR image was also reduced after corticosteroid treatment in each patient with RS3PE syndrome (data not shown).

\section{DISCUSSION}

VEGF is a potent angiogenic, ${ }^{9}{ }^{10}$ vasoactive, ${ }^{6}$ molecule which increases permeability, ${ }^{11}{ }^{12}$ first described by Senger et al in 1983. ${ }^{13}$ They partially purified a factor secreted by hepatocarcinoma cell lines that increased dye extravasations into the skin of guinea pigs. In addition, recent studies reported that serum VEGF concentrations, although not as high as RS3PE syndrome found in the present cases, correlate with disease activity in patients with inflammatory arthropathies such as rheumatoid arthritis. ${ }^{714}$

The pathogenic mechanism of RS3PE syndrome is still unknown. As far as we know, this is the first report indicating that VEGF may contribute to the pathological changes seen in patients with RS3PE syndrome; both synovial hypervascularity (synovitis) and increment of vascular permeability (subcutaneous oedema) may be facilitated by VEGF in patients with RS3PE syndrome. Serum $V$ GGF $_{165}$ levels were selectively high in active RS3PE syndrome as compared with other connective tissue diseases. This difference of serum $\mathrm{VEGF}_{165}$ may be due to the difference of corticosteroid dosage among patient groups, and we cannot exclude the possibility at present that high serum VEGF 165 concentrations in RS3PE syndrome may be a consequence of in vitro platelet activation in serum. ${ }^{15}$ However, our consecutive analysis of $\mathrm{VEGF}_{165}$ as well as MRI suggests that serum VEGF might be useful for the diagnosis and monitoring of disease activity in patients with RS3PE syndrome.

\section{Authors' affiliations}

K Arima, M Tamai, N Iwanaga, Y Izumi, M Huang, F Tanaka, M Kamachi, K Aratake, H Nakamura, H Ida, A Kawakami, K Eguchi, First Department of Internal Medicine, Graduate School of Biomedical Science, Nagasaki University, 1-7-1 Sakamoto, Nagasaki 852-8501, Japan

T Origuchi, Nagasaki University School of Health Sciences, Nagasaki University, 1-7-1 Sakamoto, Nagasaki 852-8520, Japan

M Uetani, Department of Radiology and Radiation Research, Graduate School of Biomedical Science, Nagasaki University, 1-7-1 Sakamoto, Nagasaki 852-8501, Japan

Correspondence to: Professor K Eguchi, kzarima-ngs@umin.ac.jp

Accepted 3 April 2005 


\section{REFERENCES}

1 McCarty DJ, O'Duffy JD, Pearson L, Hunter JB. Remitting seronegative symmetrical synovitis with pitting edema. RS3PE syndrome. JAMA 1985:254:2763-7.

2 Sibilia J, Friess S, Schaeverbeke T, Maloisel F, Bertin P, Goichot B, et al. Remitting seronegative symmetrical synovitis with pitting edema (RS3PE): a form of paraneoplastic polyarthritis? J Rheumatol 1999;26:115-20.

3 Tunc SE, Arslan C, Ayvacioglu NB, Sahin M, Akkus S, Yorgancigil H. Paraneoplastic remitting seronegative symmetrical synovitis with pitting edema (RS3PE syndrome): a report of two cases and review of the literature. Rheumatol Int 2004;24:234-7.

4 Oide T, Ohara S, Oguchi K, Maruyama M, Yazawa M, Inoue K, et al. Remitting seronegative symmetrical synovitis with pitting edema (RS3PE) syndrome in Nagano, Japan: clinical, radiological, and cytokine studies of 13 patients. Clin Exp Rheumatol 2004;22:91-8

5 Matsuda M, Sakurai K, Fushimi T, Yamamoto K, Rokuhara S, Hosaka N, et al. Sarcoidosis with high serum levels of vascular endothelial growth factor (VEGF), showing RS3PE-like symptoms in extremities. Clin Rheumatol 2004;23:246-8.

6 Bates DO, Harper SJ. Regulation of vascular permeability by vascular endothelial growth factors. Vascul Pharmacol 2002;39:225-37.

7 Drouart M, Saas P, Billot M, Cedoz JP, Tiberghien P, Wendling D, et al. High serum vascular endothelial growth factor correlates with disease activity of spondylarthropathies. Clin Exp Immunol 2003;132:158-62.

8 Robak E, Wozniacka A, Sysa-Jedrzejowska A, Stepien H, Robak T. Circulating angiogenesis inhibitor endostatin and positive endothelial growth regulators in patients with systemic lupus erythematosus. Lupus 2002;11:348-55

9 Jain RK. Molecular regulation of vessel maturation. Nat Med 2003;9:685-93.

10 Isner JM, Pieczek A, Schainfeld R, Blair R, Haley L, Asahara T, et al. Clinical evidence of angiogenesis after arterial gene transfer of phVEGF165 in patient with ischemic limb. Lancet 1996;348:370-4.

11 Watanabe O, Arimura K, Kitajima I, Osame M, Maruyama I. Greatly raised vascular endothelial growth factor (VEGF) in POEMS syndrome. Lancet 1996;347:702.

12 Yamauchi A, Ito Y, Morikawa M, Kobune M, Huang J, Sasaki K, et al. Preadministration of angiopoietin-1 followed by VEGF induces functional and mature vascular formation in a rabbit ischemic model. J Gene Med 2003;5:994-1004.

13 Senger DR, Galli SJ, Dvorak AM, Perruzzi CA, Harvey VS, Dvorak HF. Tumor cells secrete a vascular permeability factor that promotes accumulation of ascites fluid. Science 1983;219:983-5.

14 Klimiuk PA, Sierakowski S, Latosiewicz R, Cylwik JP, Cylwik B, Skowronski J, et al. Soluble adhesion molecules (ICAM-1, VCAM-1, and E-selectin) and vascular endothelial growth factor (VEGF) in patients with distinct variants of rheumatoid synovitis. Ann Rheum Dis 2002;61:804-9.

15 Hashiguchi T, Arimura K, Matsumuro K, Otsuka R, Watanabe O, Jonosono M, et al. Highly concentrated vascular endothelial growth factor in platelets in Crow-Fukase syndrome. Muscle Nerve 2000;23:1051-6.

\section{bmjupdates+}

bmjupdates+ is a unique and free alerting service, designed to keep you up to date with the medical literature that is truly important to your practice.

bmjupdates+ will alert you to important new research and will provide you with the best new evidence concerning important advances in health care, tailored to your medical interests and time demands.

Where does the information come from?

bmjupdates+ applies an expert critical appraisal filter to over 100 top medical journals A panel of over 2000 physicians find the few 'must read' studies for each area of clinical interest

Sign up to receive your tailored email alerts, searching access and more...

www.bmjupdates.com 